\title{
A Note on the Library Organization at the University of Texas, 1934/43
}

\author{
$M r$. Coney is librarian of the University \\ of Texas, Austin.
}

$\mathrm{T}$ HE SPAN OF YEARS from I 934 to 1943 generated in the University of Texas many changes affecting its library. The enrolment rose from 7667 individuals in the long session of $1934-35$ to a peak of 11,146 in 1940-41. The instructional staff rose from 387 individuals to more than 630 by the end of the period. During that time the university changed presidents and an appreciable number of the older faculty died or retired and were replaced by new men with different research interests. The library in 1934-35 comprised 474,000 volumes and by the end of the period had increased to 7 I 5,000 volumes. The library's archives collection had increased from something like one and one half million original documents to something over two and one half million, with correspondingly large increases in photostats and transcripts. Within that period 57,000 feet of manuscript microfilm, 7000 pieces of music, and 2400 pictures were acquired. The staff increased from thirty-five full-time individuals to fifty-seven. The period begins with the occupation of a new library building and ends with the involvement of the United States in a total war. Within that period the depression-born largess of free government labor in terms of P.W.A.,
W.P.A., and N.Y.A. came into existence and all but disappeared.

The pattern of organization at the beginning and at the end of the period is stated graphically in Figures $I$ and 2. These charts display units of work, each homogeneous with respect to character of work, bodies of materials, or functions. The charts are not intended to display the flow of work from one unit to another.

In 1934-35 twenty units out of a total of twenty-one were reporting directly to the librarian. In 1942-43 the total number of units had increased to twenty-nine, with six reporting directly to the librarian and sixteen to the associate librarian. Seven units report directly to persons intermediate between the unit and the associate librarian. In addition to the six units reporting to him, the librarian works with three individuals who do not direct work units but are staff officers (as opposed to line officers) and who act in behalf of the librarian in specialized ways. Thus the librarian's span of control has been reduced from twenty persons to seven (including the associate librarian but excluding staff officers). The lot of the associate librarian is not far different from that of the librarian at the beginning of the period with respect to numbers. It is apparent, however, on inspection of Figure 2 that eight of these units reporting to the associate are branch libraries, two 
of which operate without staffs. Since these units present similar problems, the variety of work coming to the associate librarian is somewhat reduced despite his wide span of control.

The personal knowledge and activity of the librarian is extended by three staff positions. To the bibliographer is delegated much work coming to the librarian's office on the evaluation of offers of books and the availability of new materials for the special collections, except for the rare books collection. Demands for information for news stories by the student newspaper and the ready acceptance of articles by the state and national press relating to new library acquisitions have tended to fix on some member of the staff as a part-time responsibility the preparation of such information for distribution. The position of service coordinator is an experimental staff position designed to keep the library in touch with student needs through systematic contact with members of the faculty. The service coordinator acts in behalf of the librarian as a liaison officer with the faculty, attempting to discover, from demands they intend to make on their students, the ways in which the library's service may better match clientele needs.

\section{Serials Work}

All work with serials (except for cataloging and the placing of orders) was originally handled by a single unit. Figure 2 shows to what extent and in what ways serials work has been reassigned. The ordering of serial material of all kinds remains, as formerly, with the order department, but the receipt of serials is assigned to a serials acquisition unit. Preparation for binding serials and separates (formerly handled by the periodicals unit) is assigned to a bindery preparation unit. The cataloging of serial material (formerly the specialty of one member of the cataloging department) is now handled by a serials cataloging unit. The reading room function of periodicals is now handled in conjunction with the openshelf reserve and the popular reading collections, the latter being a "public library" collection for the recreation of faculty and students. Public documents work of all kinds is handled as a separate work unit under the supervision of the person in charge of the business and social science room.

Branch libraries show a quite different organization pattern at the end from that displayed at the beginning of the period because of a policy of "stretching" branch librarians over more than one branch library. The level of performance set for most branch libraries calls for a kind of activity that might be described as "library housekeeping," namely, the orderly and systematic maintenance of the collections and conscientious liaison work between the branch library clienteles and other parts of the library system. While this function calls for library training, it does not necessarily require familiarity with the subject of the branch. This policy is recognized as a temporary one, intermediate between the situation at the beginning of the period, when the number of branches was smaller and two were operated by part-time student labor, and an ideal situation in which each would be headed by a library-trained subject specialist. It is believed that under the present circumstances economical and adequate supervision can be maintained by one branch librarian over more than one branch library, particularly when the branches contain related collections and 


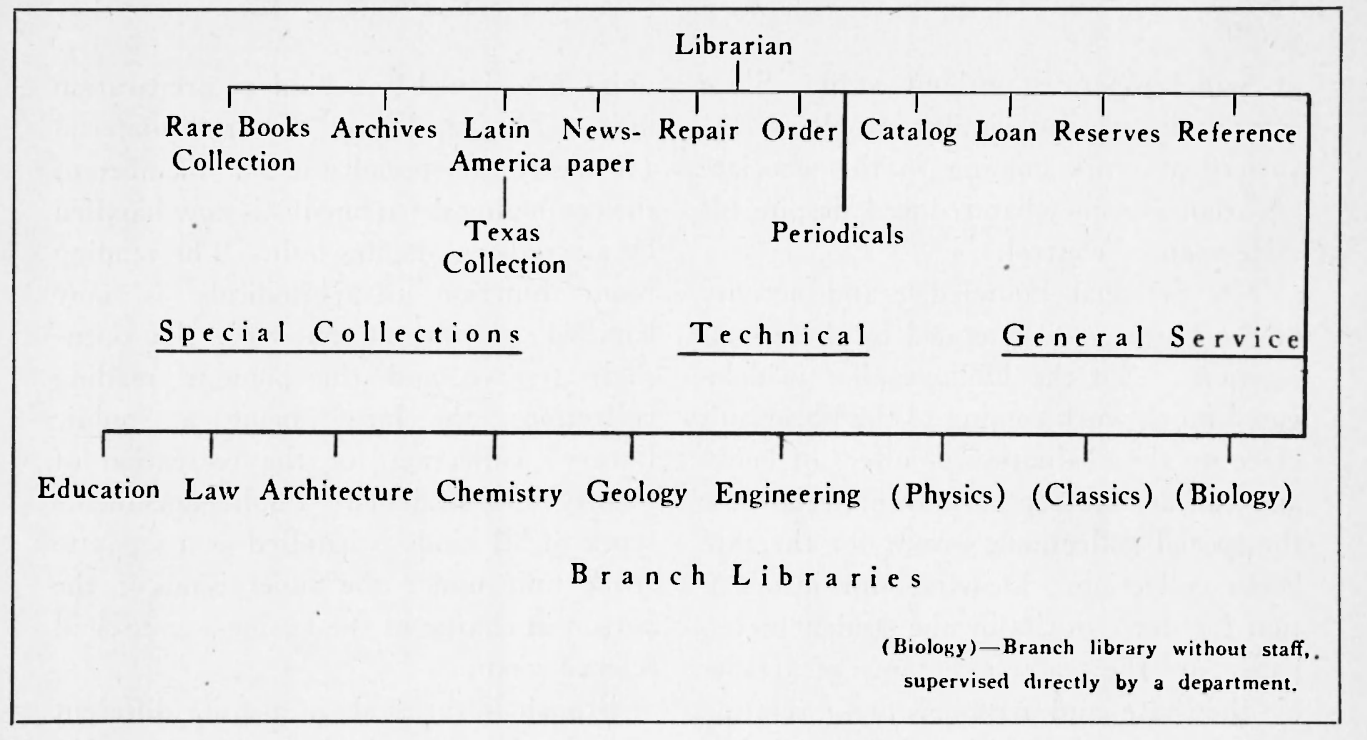

Figure I

University of Texas Library Organization, 1934-35

hence serve interrelated clienteles, as exemplified by the chemistry librarian's control of geology, engineering, and the chemical engineering laboratory collection, and the education librarian's control of the textbook and curriculum collection. A sport occurs in the control of the music library by the biology librarian. This is merely a case of exploiting the biology librarian's interest in and knowledge of music and an example of the utilization of a latent capacity when opportunity arises.

\section{Subsidiary Activities}

Subsidiary activities, which do not occupy the full time of an individual but are generally recognized library functions or which utilize the services of several persons but are definitely subsidiary in character, are not shown on the charts for reasons of simplicity. Interlibrary lending and borrowing are separated, borrowing being assigned to the reference department and lending-to other libraries and to individuals - to the loan department in accordance with the major functions of those departments. Card manufacturing (mimeographing and typing) and file maintenance are organized as small separate units, utilizing student labor, under the head of the separates cataloging unit. The loan department maintains central loan files not only for books loaned from the general collection but also for those loaned from the popular reading and open-shelf reserve collections. This department is responsible for sending overdue notices, recording. accumulated fines, and the other paper work incident to the loan process.

Aside from their responsibility for controlling specific units of the library organization, the librarian and the associate librarian divide other types of responsibility between them. The librarian is responsible for outside relationships, e.g., with the university administration, other libraries, and individuals off the campus; while the associate librarian assumes re- 


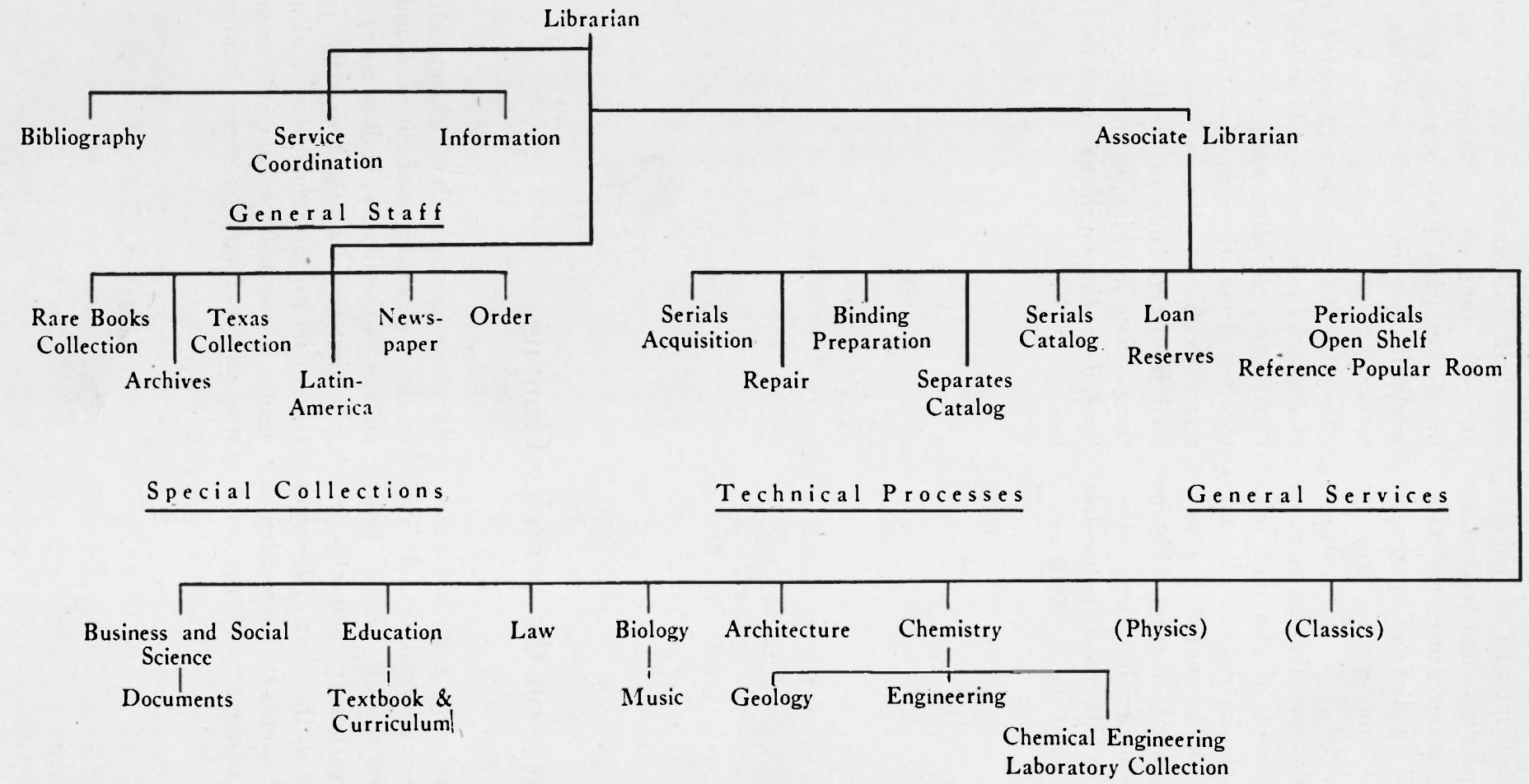


sponsibility for such internal activities as the selection of part-time and student assistants, building maintenance, the vacation schedule, and supplies and equipment. Prospects for full-time appointments are interviewed jointly.

Aside from the coordination secured through the reporting of one unit to a superior officer, horizontal coordination of activity is sought by means of a fortnightly library council, meeting with the librarian and associate librarian, whose members comprise all those responsible for important units of work. Staff meet- ings held independently by departments or work units are infrequent since the number of individuals in such groups is small and because, for the most part, they work at adjacent desks. The absence of adjacency, however, has prompted those in charge of loan work (in branches, loan department, periodical room, etc.) to meet together from time to time to discuss related problems. Recommendations proceed from this body to the librarian, to the associate librarian, or to a department head, depending on the nature of the problem.

\section{Library Service on the Berkeley Campus}

\section{(Continued from page 217)}

these conferences, many ways and means devised, and many undertakings initiated and planned in detail before being launched. In particular, and this has proved important in this time of frequent emergencies and constant unprecedented demands upon resources and personnel, they have insured a thorough understanding by the executives of the aims and the policies of the library, both in its capacity as a vital organ of the university, necessary to its proper functioning, and as an agency active in forwarding the country's war effort. That has meant teamwork. 